OPEN ACCESS

Edited by:

Qiang Ji,

Institutes of Science and Development (CAS), China

Reviewed by:

Ke-Liang Wang,

Ocean University of China, China Zhe Liu,

Xi'an Jiaotong University, China

*Correspondence:

Yuying Pan

panyuying125@163.com

Huaping Sun

shp@ujs.edu.cn

shp797@163.com

Farhad Taghizadeh-Hesary farhad@tsc.u-tokai.ac.jp farhadth@gmail.com

Xiaoran Kong xiaorankong@163.com

Specialty section:

This article was submitted to

Environmental Economics

and Management,

a section of the journal

Frontiers in Environmental Science

Received: 19 September 2020 Accepted: 09 November 2020 Published: 02 December 2020

Citation:

Kong $X$, Pan Y, Sun $H$ and Taghizadeh-Hesary F (2020) Can Environmental Corporate Social

Responsibility Reduce Firms' Idiosyncratic Risk? Evidence From China. Front. Environ. Sci. 8:608115. doi: 10.3389/fenvs.2020.608115

\section{Can Environmental Corporate Social Responsibility Reduce Firms' Idiosyncratic Risk? Evidence From China}

\author{
Xiaoran Kong ${ }^{1 *}$, Yuying Pan ${ }^{1 *}$, Huaping Sun ${ }^{2 *}$ and Farhad Taghizadeh-Hesary ${ }^{3 *}$ \\ ${ }^{1}$ College of Finance, Shandong University of Finance and Economics, Jinan, China, ${ }^{2}$ School of Finance and Economics, \\ Jiangsu University, Zhenjiang, China, ${ }^{3}$ Social Science Research Institute, Tokai University, Kanagawa, Japan
}

Environmental corporate social responsibility (ECSR) can be a strategy to increase the transparency of investment information effectively to alleviate information asymmetry. The purpose of this article is to examine the impact of ECSR on firms' idiosyncratic risk. Using the data of A-share listed firms in China and data of Rankins CSR Ratings by developing econometrics models, this study documents that ECSR can significantly reduce the firms' idiosyncratic risk. This result perpetuates after a series of robustness checks. Besides, the results of conditional analyses reveal that the effect of ECSR is more pronounced for state-owned firms and firms with weaker external monitoring mechanisms and low internal control. Moreover, further evidence suggests that firms with high ECSR show a greater tendency to disclose more information, which reduces the information asymmetry and offers linkages from ESCR to firms' idiosyncratic risk.

\footnotetext{
Keywords: environmental corporate social responsibility, ECSR, idiosyncratic risk, information transparency, information asymmetry
}

\section{INTRODUCTION}

The rapid development of the Chinese economy has brought severe environmental problems. Thus, there is a strong calling for firms to disclose environmental information, and environmental information has gradually become an essential consideration for stakeholders to make decisions (Benlemlih et al., 2018; Cordeiro et al., 2020). Prior studies have confirmed that environmental corporate social responsibility (ECSR) plays a vital role in the operations of firms (Cai et al., 2016). ECSR contributes to enhance firm reputation and obtain a positive market reaction (Khojastehpour and Johns, 2014; Cordeiro and Tewari, 2015). Besides, firms with good ECSR have better long-term financial performance and lower cost of equity capital and debt capital cost (Jo et al., 2015; El Ghoul et al., 2018; Luo et al., 2019). Unlike the prior studies, this article attempts to explore the impact of ECSR on the idiosyncratic risk of listed Chinese firms, and its purpose is to understand the role of environmental and social responsibility in corporate governance. The research conclusions provide strong evidence for enriching the corporate governance system and alleviating the conflicts between firms and stakeholders and promoting economic, social, and environmental development.

As an essential subset of corporate social responsibility, ECSR includes the overall environmental information of firms, pollution prevention measures, resource-saving measures, and so on (Luo et al., 2012; Matsumura et al., 2014; Chatzoglou et al., 2017). Previous studies have found that firms with good performance in ECSR are more likely to succeed (Barnea and Rubin, 2010). On the one hand, active disclosure 
of ECSR can enhance the corporate reputation and win consumers and stakeholders (Luo et al., 2012; Matsumura et al., 2014). On the other hand, high-quality ECSR also plays a positive role in coordinating the relationship between stakeholders (Orlitzky and Benjamin, 2001; Tencati et al., 2004; Connelly et al., 2011; Salama et al., 2011). Therefore, ECSR can send a signal to the public that the company's behavior is legal and that the company attaches importance to environmental protection (Tzouvanas et al., 2020). This signal reduces the degree of information asymmetry, increases the transparency of information, and improves the effectiveness of investors' decision-making.

Idiosyncratic volatility is the volatility of stock returns beyond systematic risk, reflecting the unique risk of firms. Idiosyncratic risk accounts for a large proportion of firms' total risks (Goyal and Santa-Clara, 2003; Gaspar and Massa, 2006) and is an essential factor affecting stock returns. High idiosyncratic volatility indicates that the guiding role of the stock price on capital flow is relatively weak and that the capital market may have defects in resource allocation (Bansal and Clelland, 2004; Fan et al., 2015; Hu et al., 2020). Prior research results show that up to standard information disclosure contributes to the reduction in the degree of investors' cognitive divergence on stock value, thus improving the pricing efficiency of the market model and reducing the stock idiosyncratic volatility (Jiang et al., 2009; Lee and Liu, 2011; Ziegler et al., 2011). Considering that ECSR is conducive to improve information disclosure, we speculate that ECSR can significantly reduce idiosyncratic risk.

We focus on the Chinese stock market for two primary reasons. First, Chinese ECSR started late. Thus, the concept of environmental information disclosure has not been popularized, and firms pay insufficient attention to the practice of environmental, social responsibility (Tian et al., 2016; Zhang et al., 2020). According to the scores of ECSR published by Rankins CSR Ratings, in 2018, 3 years after the enforcement of the New Environmental Protection Law, the average score of ECSR of listed firms in China was 17.913, which is far below the passing line (out of 45 points). Even worse, firms tend to disclose good news instead of bad news and pay more attention to quantity than quality (Luo et al., 2019). More importantly, with the continuous economic development, people's demand for a better ecological environment increases day by day ( $\mathrm{Li}$ et al., 2019, 2020). This, in effect, creates an alarming concern for the government. After the 18th National Congress of the Communist Party of China, environmental protection has become an essential part of the ecological civilization construction system. The government abandoned the treatment after pollution strategy and explored a path of green development that pays equal attention to development and environmental protection instead. Accordingly, the Chinese government has been putting forward higher requirements for firms to fulfill their sustainable development (Ye et al., 2015; Yang et al., 2020). The new Environmental Protection Law, which was officially implemented on January 01,2015 , significantly added "information disclosure and public participation." It explicitly required listed firms in heavy-pollution industries to disclose their environmental information and accept social supervision.
Simultaneously, the law also has a particular deterrent effect on listed firms in non-heavy-pollution industries. In general, ECSR in China started late but made significant progress. Based on this background, this study can highlight the role of environmental information disclosure.

Second, the Chinese stock market serves as an ideal platform for this study. On the one hand, the Chinese stock market is still immature, and the quality of listed firms is uneven. For this reason, the fluctuation of stock prices is multifarious ( $\mathrm{Gu}$ et al., 2019). On the other hand, as significant participants in the Chinese stock market, retail investors are easily misled by false information. Therefore, to reduce investors' cognitive differences and stabilize stock prices, Chinese listed firms urgently need to improve ECSR (Dai and Yin, 2017). These backgrounds give us superiorities to explore how ECSR affects idiosyncratic risk.

Using a sample of Chinese A-share stocks disclosed environmental information from 2011 to 2017, this article explores the relationship between ECSR and firms' idiosyncratic risk. First of all, the empirical results show that the higher the ECSR score, the lower the idiosyncratic risk. To further exclude the impact of potential endogeneity in this article, we conducted a battery of robustness checks such as changing indicators, firm fixed-effects model, using of instrumental variables, and adopting propensity score matching (PSM). After the above robustness checks, our main results continue to hold. Also, we explored the mechanism of ECSR. By identifying the internal mechanism, we found that exceptional ECSR can effectively improve the level of information transparency and alleviate the information asymmetry. The improvement of the information disclosure level reduces idiosyncratic risk. Finally, we further examined the impact of ECSR on idiosyncratic risk under different firm characteristics and monitoring mechanisms. Evidence shows that the effect of ECSR is more substantial for state-owned firms, smaller firms, low-leverage firms, and firms with weaker external monitoring mechanisms.

The characteristics of this article are as follows. First, our empirical evidence enriches the emerging literature on corporate social responsibility. Most prior studies have discussed the impact of corporate social responsibility on corporate value, cost of equity capital, and cash holdings value (Gregory et al., 2014; Wu et al., 2014; Arouri and Pijourlet, 2017). With the deterioration of environmental problems and the awakening of public environmental protection, ECSR has gradually attracted the attention of the government and researchers. However, related research mainly focuses on the impact of ECSR on financial performance (Ambec and Lanoie, 2008; Cai and $\mathrm{He}$, 2014; Chava, 2014). This article explores the role and mechanism of ECSR on idiosyncratic risk and consequently provides a useful supplement for additional research in this field.

Second, this article provides a new perspective on the study of firms' idiosyncratic risk. Earlier literature has heated discussions on whether the negative relationship between idiosyncratic volatility and stock expected returns exists. They have tried to solve the "mystery of idiosyncratic volatility" (Ang et al., 2006, 2009; Huang et al., 2010; Zuo et al., 2011). Besides, some researchers have found that many factors are positively related to idiosyncratic volatility such as institutional herd 
behavior, CEO equity incentives, the age of board members, the "lottery preference" of investors, and selective disclosure of firm information (Chang and Dong, 2006; Chok and Sun, 2007; Barberis and Huang, 2008; Jiang et al., 2009). Improving the quality of financial statements and enhancing the management ability of the CEO can reduce the idiosyncratic risk (Fu et al., 2015; Tan and Liu, 2016). As one of the critical strategic decisions of the firm, the role of ECSR is often ignored. Therefore, our empirical analyses examine the process of environmental, social responsibility disclosure affecting idiosyncratic risk and expand the literature on the impact of idiosyncratic risk.

Third, this study provides a reference for understanding the mechanism of ECSR. The empirical results show that the higher the disclosure of ECSR, the higher the information transparency, and the lower the idiosyncratic risk. This conclusion provides a necessary theoretical basis for promoting an information disclosure system and enriching the methods of governance means.

Finally, the previous studies on ECSR were mostly concentrated on Western developed countries. This study was conducted under the institutional background of China, an emerging economy, and unlike the researches on heavypollution industries, we considered the heterogeneity among industries and selected the samples covering most industries listed in A-shares in China. The emerging economies usually achieve high-speed development at the cost of environment at the initial stage, so the environmental problems of developing countries are more serious. Under this condition, it will be more practical to test the role of ECSR. Firms are the indispensable force for environmental protection. This research contributes to improving the environmental protection awareness of firms so as to relieve the government of environmental pressure. It provides not only an opportunity to check the theories from developed countries but also a reference for researchers to study the practice of ECSR in China.

The remainder of this article is organized as follows. Section "Institutional Background and Hypothesis Development" analyzes the evolution of the Chinese environmental disclosure system and presents the research hypotheses. Section "Research Design" describes the data and gives the methodologies used to examine the effect of ECSR on idiosyncratic risk. Section "Empirical Results" shows our empirical results. The last section concludes the article.

\section{INSTITUTIONAL BACKGROUND AND HYPOTHESIS DEVELOPMENT}

\section{Evolution of Environmental Information Disclosure System}

The Environmental Information Disclosure Measures (Trial) issued in 2007 provides a standard for firms to disclose environmental information. After that, Chinese regulatory authorities have issued a series of laws and regulations related to environmental protection. The continuous improvement of laws and regulations on environment has strongly urged firms to fulfill their environmental responsibilities. According to the Evaluation
Report on Environmental Responsibility Information Disclosure of Listed Companies in China (2018) jointly issued by China Forum of Environmental Journalists and Beijing University of Chemical Technology in 2018, the number of firms publishing social responsibility or environmental responsibility reports in China was 1,646, accounting for 56.38\%. Furthermore, the level of ECSR in listed firms is increasing year by year.

\section{Hypothesis Development}

It is difficult for investors with limited information to correctly evaluate firm value. This is the main reason for the stock idiosyncratic volatility (Liu et al., 2014). For firms that disclose environmental responsibility less, their stakeholders (such as shareholders, customers, consumers, and so on) tend to think that firms have the possibility of hiding harmful environmental information. Thus, the tendency reduces the pricing efficiency of market models and increases the stock idiosyncratic risk (Ziegler et al., 2011). However, social responsibility disclosure establishes a healthy connection between firms and stakeholders and protects insurance for firms to face risks smoothly (Godfrey, 2005; Godfrey et al., 2009).

Extant studies have interpreted the impact of corporate social responsibility on firms' idiosyncratic risk (Mishra and Modi, 2013; Chen and Liu, 2019; Ozdemir et al., 2020). A few researchers examined the relationship between ECSR and idiosyncratic risk from the perspective of environmental protection. The results show that high-quality environmental information disclosure can reduce the information asymmetry between firms and participants in securities market and can decrease firms' idiosyncratic risk (Benlemlih et al., 2018; Tzouvanas et al., 2020). However, these studies focus on the developed countries and states in Europe such as Britain, and measures of ECSR are from a single perspective. Therefore, we used indicators that cover more aspects of firms' environmental performance comprehensively to test whether the relationship is true in China, an emerging economy. Based on the above arguments, we propose the first hypothesis:

Hypothesis 1: The improvement of ECSR disclosure quality is beneficial to firms' idiosyncratic risk reduction

Information asymmetry, which creates lack of reliable basis for investors to predict the future cash flow of listed firms, is expected under the real market conditions. Therefore, those firms with worse information transparency have higher idiosyncratic risk (Bushee and Noe, 2000; Jiang et al., 2009). It has been proven that active disclosure of ECSR can reduce the information uncertainty faced by financial analysts and enables them to make more accurate profit forecasts (Cormier et al., 2010; Cormier and Magnan, 2014, 2015). Besides, ECSR can be a strategy to increase the transparency of investment information effectively (Cai et al., 2012). Specifically, firms actively disclosing environmental information meet the expectations of the public, so this behavior is conducive to shaping a responsible image (Toms, 2002; Hasseldine et al., 2005). It can also send a signal to the outside that operations are legal and stable and provide investors with reliable information besides financial statements (Ben-Amar and McIlkenny, 2015). Also, there are 
consumers, suppliers, employees, and other stakeholders except for shareholders. Firms need to reconcile all main stakeholders to gain a competitive advantage (Jones, 1995). High-quality ECSR not only can meet the information needs of stakeholders, but also promote the establishment of a strong relationship between firms and stakeholders (Orlitzky and Benjamin, 2001; Connelly et al., 2011; Salama et al., 2011; Shahzad et al., 2018). The possibility of hiding harmful environmental information is significantly reduced under the joint supervision of stakeholders, and the transparency of information is improved. Thus, the increase in corporate environmental responsibility information disclosure provides a guarantee for investors to obtain sufficient information so that they can make wiser decisions. Based on the above arguments, we propose the following research hypothesis:

Hypothesis 2: ECSR can improve the level of information transparency, alleviate information asymmetry, and thus reduce firms' idiosyncratic risk.

Corporate governance, external supervision, and the relationship between firms and the government are important factors that affect firms' idiosyncratic risk. High governance, strong external supervision mechanisms, and the nature of state-owned firms help in reducing firms' idiosyncratic risk (Ferreira and Laux, 2007; Abad and Robles, 2014; Chen and Liu, 2019; Phi et al., 2020). Based on the above three factors, we speculate that the impact of ECSR on idiosyncratic risk has heterogeneity under different conditions.

According to the principal-agent theory, improving the level of information disclosure can alleviate information asymmetry (Yoshino and Taghizadeh-Hesary, 2014, 2015), thus reducing agency costs. To increase the firm value, firms with adequate governance levels may improve voluntary information disclosure (Bi et al., 2012; Lu and Abeysekera, 2014; Wu et al., 2014). The firm scale is considered to be a powerful indicator that affects the disclosure of corporate social environment. Largescale firms face more social supervision, so they tend to unveil more information to obtain sustained support from investors (Hackston and Milne, 1996; Cormier and Gordon, 2001; Liu and Anbumozhi, 2009). The betterment of information disclosure can convince investors of investment safety and then attract followup financial support. High-leverage firms usually strengthen information disclosure to achieve a win-win situation with creditors. In effect, creditors can use the information obtained to evaluate the firm's operation and supervise the management's behavior and then reduce the possibility of concealing bad news (McMullen and Ragahunandan, 1996).

Similarly, the external supervision mechanism is also helpful in improving corporate governance and information disclosure (Meng et al., 2013). Under the unique background that the overall level of environmental information disclosure is low, the inhibitory effect of ECSR on idiosyncratic risk in the substantial external supervision firms may be concealed. Therefore, in firms with weak corporate governance, the role of corporate environmental responsibility may be more prominent.

State-owned firms are in the leading position in China's market economy (Taghizadeh-Hesary et al., 2019). The natural lineage ties between state-owned firms and the government make them significantly different from private firms with regards to resource endowment, external supervision, policy support, and business objectives (Yang et al., 2011). Therefore, compared with private firms, state-owned firms have a more significant initiative to fulfill their environmental responsibilities, and their information disclosure quality is higher. Thus, ECSR has a more substantial inhibitory effect on idiosyncratic risk. To sum up, in firms with different corporate characteristics and external supervision levels, the influence of ECSR may be different. Based on the above arguments, we propose the following research heterogeneity hypothesis:

Hypothesis 3: In firms with low governance levels, weak external supervision mechanism, and state-owned firms, the role of ECSR in reducing idiosyncratic risk is more prominent.

\section{RESEARCH DESIGN}

\section{Sample}

The sample used in this study, collected from the China Stock Market and Accounting Research (CSMAR) database and the RESSET database, initially comprises all firms listed on the Shanghai Stock Exchange and Shenzhen Stock Exchange. Also, the score of ECSR comes from Rankins CSR Ratings (RKS). We set the sample interval as 2011-2017. Following the sample selection criteria in related literature, our sample excludes firms in the financial sector and firms with incomplete financial data. Then, we excluded firms listed less than 1 year during this period. All continuous variables are winterized by $1 \%$. Finally, our full sample consists of 3,104 firm-year observations.

\section{Variables}

\section{Measures of Idiosyncratic Risk}

Following Ang et al. (2006) and Tzouvanas et al. (2020), we use the Fama-French three-factor model to estimate the idiosyncratic risk:

$$
\begin{gathered}
R_{i, t}-r_{f, t}=\alpha_{i}+\beta_{i}^{M K T}\left(R_{m, t}-r_{f, t}\right)+\beta_{i}^{S M B} S M B_{t}+ \\
\beta_{i}^{H M L} H M L_{i}+\varepsilon_{i, t}
\end{gathered}
$$

Since the financial data in this article are annual, we used monthly data to estimate the model. In the model, $R_{i, t}$ is the return on stock $i$ in month $t ; r_{f, t}$ is the risk-free interest rate in month $t ; R_{m, t}$ is the returns on the market in month $t ; S M B_{t}$, $H M L_{t}$ is the size factor, book to market ratio factor of firm $i$ in month $t$, respectively; $\varepsilon_{i, t}$ is the residual term. Then, we used the annualized standard deviation of the residual term to calculate the annual idiosyncratic volatility of the company's stock:

$$
\operatorname{Risk}_{i, t}=\sqrt{\operatorname{Var}\left(\varepsilon_{i, t}\right)}
$$

\section{Measures of ECSR}

Referring to methods utilized by Elmagrhi et al. (2019) and Luo et al. (2019), this article selects $\mathrm{RKS}^{1}$, a social rating

${ }^{1}$ http://www.rksratings.cn/ 
agency, to measure the ECSR. RKS is a third-party rating agency for CSR of Chinese listed firms. RKS rating system is consistent with ISO26000. Thus, it is independent and scientific. The system includes four aspects: macrocosm, content, technique, and industry. In terms of content scoring $(C)$, the experts score based on 6 primary indicators and 45 secondary indicators, including environmental category (pollution control, environmental recovery, energy saving or reutilization of waste material, environmentally friendly products, and other environmental disclosure), employee category (health and safety of employee, staff training, performance evaluation, welfare), and social category (tax payment, public welfare or other donations), and consumers category (product quality and safety). The scoring results are therefore compared with scoring based on self-developed evaluation system and objective and show a high degree of specialization (Xiang et al., 2020). Besides, it eliminates the subjectivity of standard selection and scoring in index construction by oneself (Zhang et al., 2016). Therefore, because of the availability, this study used content scoring (C) released by RKS as an alternative variable to the level of corporate ECSR.

\section{Other Control Variables}

To analyze the real impact of ECSR on idiosyncratic risk, according to previous literature (Jo and Na, 2012; Servaes and Tamayo, 2013; Jo et al., 2015), we controlled the following variables in the empirical model: (1) SIZE, the natural logarithm of the total assets at the end of the period; (2) BTM, the book-to-market ratio; (3) $R O A$, the return on assets, that is, the ratio of net profit to total assets; (4) $L E V$, the assetliability ratio of listed companies, the ratio of total liabilities to total assets; (5) LOSS, if the net profit of the listed companies in year $t$ is less than 0 , it is assigned as 1 ; otherwise, it is 0; (6) GROWTH, annual sales growth rate; (7) $B O A R D$, the size of the board of directors, which is measured by the total number of directors; and (8) RET, the annual stock return considering the reinvestment of cash dividends. Besides, referring to Benlemlih et al. (2018) and El Ghoul et al. (2018), this article also controls the fixed effects of year and industry.

\section{Models Specification}

To examine the impact of ECSR on idiosyncratic risk, we constructed the following model:

$$
\begin{gathered}
\text { RISK }_{\mathrm{i}, \mathrm{t}+1}=\beta_{0}+\beta_{1}^{*} \mathrm{ECSR}_{\mathrm{i}, \mathrm{t}}+\sum_{\mathrm{k}} \gamma_{\mathrm{k}} \text { Control }_{\mathrm{k}, \mathrm{i}, \mathrm{t}}+ \\
\text { Year, Industry fixed effects }+\varepsilon_{\mathrm{i}, \mathrm{t}}
\end{gathered}
$$

Where Risk $_{i, t+1}$ is the idiosyncratic risk of firm $i$ in year $t+1$; $E C S R_{i, t}$ is the ECSR score of firm $i$ in year $t$; and Control $_{k, i, t}$ is the set of control variables that defined at the above section. To mitigate potential problems that may arise from omitting timeinvariant and industry-specific characteristics, we also controlled the year fixed effects and industry fixed effects. If Hypothesis 1 is tenable, the coefficient $\beta_{1}$ in the model (3) should be significantly negative, which means that ECSR will weaken the firm idiosyncratic risk.

\section{EMPIRICAL RESULTS}

\section{Descriptive Statistics and Correlations}

Tables 1, 2 present descriptive statistics and Pearson correlation coefficient matrix for the variables used in our regressions. As shown in Table 1, the mean value of $R I S K_{t+1}$ is 0.068 , and the standard deviation is 0.021 . This shows that the volatility of idiosyncratic risk of different firms varies greatly. Besides, the highest score of $E C S R_{t}$ is 34.1, and there is still a big gap with the full score of 45 . This is consistent with the actual situation of uneven disclosure of ECSR in China. At the same time, the statistical results of other control variables are in the normal range.

The results in Table 2 show that the $\mathrm{ECSR}_{t}$ has a significant negative correlation with the idiosyncratic risk (RISK) at a $1 \%$ level, with a correlation coefficient of -0.103 . This result indicates that ECSR can effectively reduce the firm's idiosyncratic risk in the future and provides initial evidence on Hypothesis 1. Moreover, the correlation between other control variables and idiosyncratic risk is in line with expectations, which indicates that these variables will also affect future risk. Therefore, it is necessary to control these potential factors in further study.

\section{Univariate Tests}

We divided the full sample into the low-ECSR group (whose ECSR is lower than the median) and the high-ECSR group (whose ECSR is higher than the median) based on the median value of listed firms' ECSR. Then we examined the differences in the mean of the key variables between the two groups. The results of Table 3 show that the mean of the idiosyncratic risk is $6.9 \%$ for the low ECSR group and $6.6 \%$ for the high ECSR group. The difference is significant at the $1 \%$ level, indicating that firms with a higher ECSR score have less risk. The result further provides evidence of a negative correlation between ECSR and firms' idiosyncratic risk. Besides, there are significant differences between the two groups of control variables. On average, firms with higher ECSR scores have a larger scale and better earnings and have a higher BTM, leverage ratio, and individual stock return. The above results are consistent with our expectations.

\section{Multivariate Analyses}

We standardized the variables to remove the dimensions of variables before regression. In Table 4, we report the results of four regression models on the impact on ECSR on idiosyncratic risk based on Eq. (3). Columns (1) and (2) show OLS regression results, and columns (3) and (4) show GLS regression results. As observed in columns (1) and (3), where all control variables are excluded, we find that the coefficients on $E C S R_{t}$ are significantly negative $(-0.102$ with $t$-value $=-6.003$ and -0.093 with $t$-value $=-4.612)$. In columns (2) and (4), when all control variables are 
TABLE 1 | Descriptive statistics.

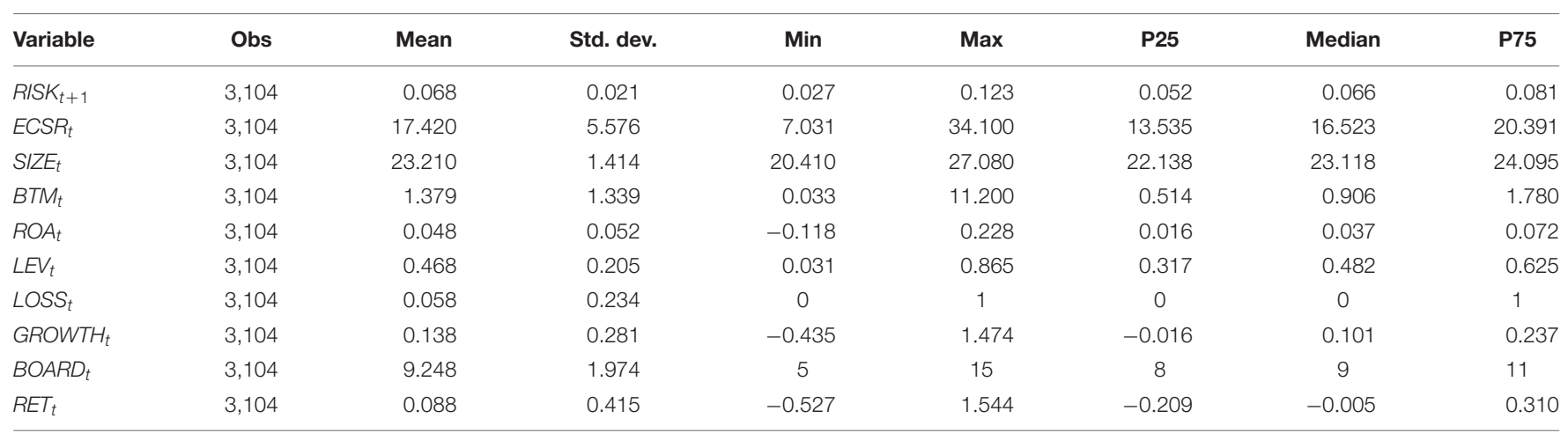

This table displays descriptive statistics for the variables. Mean, standard deviation, Q1, median, Q3, minimum, and maximum of each variable are reported. Our dependent variable (RISK $K_{t+1}$ ) is calculated by Fama-French three-factor model (Ang et al., 2006; Tzouvanas et al., 2020). Following the Luo et al. (2019) approach, we use the content score (C-value) released by RKS from 2011 to 2017 as an alternative variable to the level of environmental corporate social responsibility (ECSR $R_{t}$. Definitions of all control variables are presented in Other Control Variables.

TABLE 2 | Correlation coefficients.

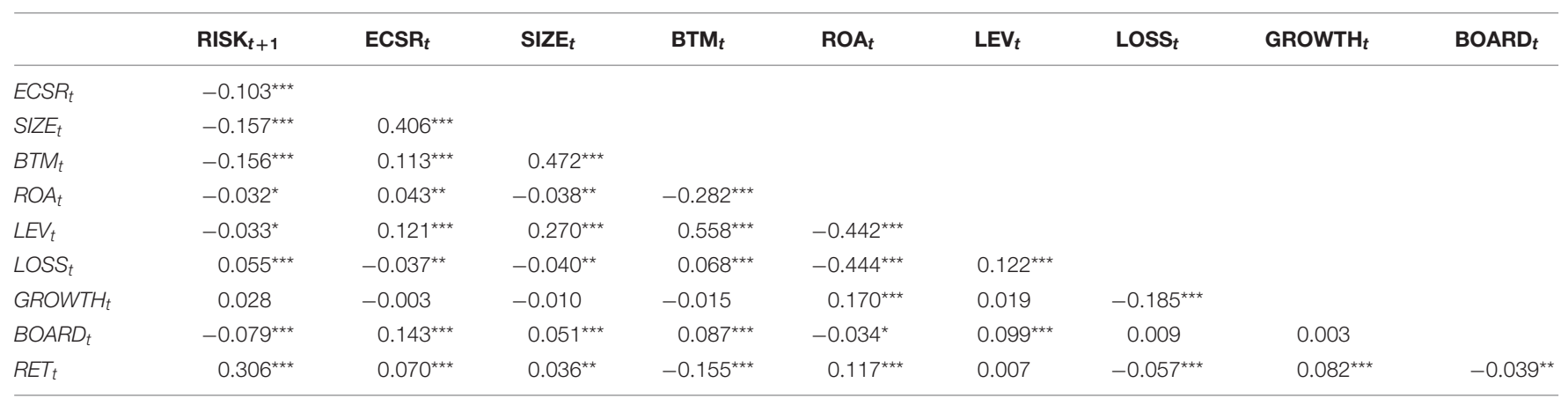

This table reports the Pearson correlation between the regression variables. The superscript asterisks ${ }^{* * *}{ }^{* *}$, and ${ }^{*}$ denote two-tailed statistical significance at the 1,5 , and $10 \%$ levels, respectively. The following tables are the same.

TABLE 3 | Univariate tests.

\begin{tabular}{|c|c|c|c|c|}
\hline & Low ECSR(1) (Obs. = 1,528) & High ECSR(2) (Obs. = 1,576) & Difference (1) - (2) & $t$-test (1) - (2) \\
\hline$S I Z E_{t}$ & 22.820 & 23.580 & -0.762 & $-15.586^{\star \star \star}$ \\
\hline$R O A_{t}$ & 0.045 & 0.051 & -0.006 & $-3.406^{\star \star \star}$ \\
\hline$L E V_{t}$ & 0.451 & 0.484 & -0.033 & $-4.468^{\star \star \star}$ \\
\hline LOSS $_{t}$ & 0.069 & 0.047 & 0.022 & $2.674^{\star \star \star}$ \\
\hline$B O A R D_{t}$ & 9.008 & 9.482 & -0.474 & $-6.731^{\star \star \star}$ \\
\hline$R E T_{t}$ & 0.061 & 0.114 & -0.053 & $-3.589^{\star \star \star}$ \\
\hline
\end{tabular}

This table reports mean difference tests of the regression variables across the low-ECSR (below median environmental corporate social responsibility) and highECSR (above median environmental corporate social responsibility) subsamples. The sample is merged across three databases, RKS, CSMAR, and RESSET over the period 2011-2017.

included, the negative relationship is still existing and relatively significant $(-0.061$ with $t$-value $=-3.429$ and -0.051 with $t$-value $=-2.585)$. Taken together, the result implies that there is a strong negative correlation between ECSR and the firms' idiosyncratic risk in the future. At the same time, the coefficients on the control variables are relatively consistent with prior studies (Cai et al., 2012; Servaes and Tamayo, 2013; Benlemlih et al., 2018). For example, firms with larger corporate value, higher BTM, and higher ROA are associated with lower risk.

\section{Robustness Tests \\ Alternative Measures of ECSR}

The ECSR score is obtained by manual scoring, although RKS's evaluation system can weaken the subjectivity of scoring to 
TABLE 4 | Results for the effect of environmental corporate social responsibility on firms' idiosyncratic risk.

\begin{tabular}{|c|c|c|c|c|}
\hline \multirow{3}{*}{$\begin{array}{l}\text { Dependent variables } \\
\text { Models }\end{array}$} & \multicolumn{4}{|c|}{ RISK $_{t+1}$} \\
\hline & \multicolumn{2}{|c|}{ OLS } & \multicolumn{2}{|c|}{ GLS } \\
\hline & (1) & (2) & (3) & (4) \\
\hline$E C S R_{t}$ & $\begin{array}{l}-0.102^{\star \star \star} \\
(-6.003)\end{array}$ & $\begin{array}{l}-0.061^{\star \star \star} \\
(-3.429)\end{array}$ & $\begin{array}{l}-0.093^{\star \star \star} \\
(-4.612)\end{array}$ & $\begin{array}{l}-0.051^{\star \star \star} \\
(-2.585)\end{array}$ \\
\hline$S I Z E_{t}$ & & $\begin{array}{l}-0.107^{\star \star \star} \\
(-5.920)\end{array}$ & & $\begin{array}{l}-0.084^{\star \star \star} \\
(-3.482)\end{array}$ \\
\hline$B T M_{t}$ & & $\begin{array}{l}-0.074^{\star \star \star} \\
(-3.601)\end{array}$ & & 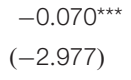 \\
\hline$R O A_{t}$ & & $\begin{array}{l}-0.072^{\star \star \star} \\
(-3.559)\end{array}$ & & $\begin{array}{l}-0.062^{\star \star \star} \\
(-3.051)\end{array}$ \\
\hline$L E V_{t}$ & & $\begin{array}{c}0.011 \\
(0.493)\end{array}$ & & $\begin{array}{c}0.003 \\
(0.104)\end{array}$ \\
\hline $\operatorname{LOSS}_{t}$ & & $\begin{array}{l}0.179^{\star \star} \\
(2.239)\end{array}$ & & $\begin{array}{l}0.170^{\star \star} \\
(2.204)\end{array}$ \\
\hline $\mathrm{GROWTH}_{t}$ & & $\begin{array}{c}0.020 \\
(1.135)\end{array}$ & & $\begin{array}{c}0.019 \\
(1.159)\end{array}$ \\
\hline$B O A R D_{t}$ & & $\begin{array}{l}-0.049^{\star \star \star} \\
(-3.104)\end{array}$ & & $\begin{array}{l}-0.036^{\star \star} \\
(-1.964)\end{array}$ \\
\hline$R E T_{t}$ & & $\begin{array}{c}0.309^{\star \star \star} \\
(16.687)\end{array}$ & & $\begin{array}{l}0.164^{\star \star \star} \\
(9.660)\end{array}$ \\
\hline Constant & $\begin{array}{l}-0.010 \\
(-0.542)\end{array}$ & $\begin{array}{c}-0.015 \\
(-0.890)\end{array}$ & $\begin{array}{c}-0.074 \\
(-0.354)\end{array}$ & $\begin{array}{c}0.034 \\
(0.173)\end{array}$ \\
\hline Year effects & Yes & Yes & Yes & Yes \\
\hline Industry effects & Yes & Yes & No & Yes \\
\hline Observations & 3,104 & 3,104 & 3,104 & 3,104 \\
\hline Adjusted $R^{2}$ & 0.011 & 0.139 & 0.326 & 0.339 \\
\hline
\end{tabular}

This table reports random-effects panel regression estimates for the relation between ECSR and idiosyncratic risk. Models (1) and (3) of Table show the regression results without control variables, whereas models (2) and (4) show the regression results with all control variables. All the coefficients reported have been standardized to remove the units of variables and facilitate the comparison of coefficients, and all continuous variables are winsorized at 1 and 99\%. The tables below are the same.

a certain extent, it cannot altogether avoid the problem of measurement error. Therefore, we divided the ECSR score into four levels of 1-4, which is used to replace the specific score in the original model (Tong et al., 2020). It not only takes into account the heterogeneity of the ECSR but also reduces the measurement error caused by subjective judgment in the scoring process.

In addition, we used the score of environmental social responsibility from the third party, "HEXUN" website, as another measurement method of ECSR. The HEXUN website evaluates the sustainability and environmental performance of Chinese listed companies from five aspects: environmental protection consciousness, environmental management system certification, environmental protection investment amount, saving energy, and emission species number, and it comprehensively reflects the level of ECSR. These databases have been widely used in relevant Chinese studies (e.g., Han et al., 2019; Chen and Hamilton, 2020; Shahab et al., 2020). The empirical results are shown in columns (1) and (2) of Table 5. The coefficient of ECSR $R_{t}$ is still significantly negative, and the results are stable.

\section{Fixed-Effect Regressions}

To mitigate potential problems that may arise from firm-specific characteristics, we re-estimated the regressions using firm fixed effects. In this way, we explored how firms' idiosyncratic risk varies with the changes in the ECSR of the same firms (Cai et al., 2016). The result in columns (3) in Table 5 indicates that the higher $\mathrm{ECSR}_{t}$, the lower the idiosyncratic risk, which also gives strong support to Hypothesis 1.

\section{Endogeneity \\ IV approach}

The omitted variables bias and self-selection problem may cloud the interpretation of the causal relation between ECSR and firms' idiosyncratic risk. Therefore, to alleviate these problems, we employed the instrumental variables estimation method.

TABLE 5 | The relation between environmental corporate social responsibility and firms' idiosyncratic risk in robustness check.

\begin{tabular}{|c|c|c|c|c|}
\hline \multirow{2}{*}{$\begin{array}{l}\text { Dependent variables } \\
\text { Models }\end{array}$} & \multicolumn{4}{|c|}{ RISK $_{t+1}$} \\
\hline & GLS & GLS & FE & 2SLS \\
\hline & (1) & (2) & (3) & (4) \\
\hline \multirow[t]{2}{*}{$E C S R_{t}$} & $-0.047^{\star \star}$ & $-0.033^{\star}$ & $-0.076^{\star \star}$ & $-0.097^{\star \star}$ \\
\hline & $(-2.565)$ & $(-1.922)$ & $(-2.127)$ & $(-1.986)$ \\
\hline \multirow[t]{2}{*}{$S I Z E_{t}$} & $-0.091^{\star \star \star}$ & $-0.102^{\star \star \star}$ & 0.038 & $-0.065^{\star *}$ \\
\hline & $(-3.908)$ & $(-4.441)$ & $(0.552)$ & $(-2.183)$ \\
\hline \multirow[t]{2}{*}{$B T M_{t}$} & $-0.069^{\star \star \star}$ & $-0.058^{\star \star}$ & $0.086^{\star \star}$ & $-0.078^{\star \star \star}$ \\
\hline & $(-2.905)$ & $(-2.447)$ & $(2.441)$ & $(-3.099)$ \\
\hline \multirow[t]{2}{*}{$R O A_{t}$} & $-0.063^{\star \star \star}$ & $-0.064^{\star \star \star}$ & -0.029 & $-0.061^{\star \star \star}$ \\
\hline & $(-3.059)$ & $(-3.060)$ & $(-1.103)$ & $(-2.925)$ \\
\hline \multirow[t]{2}{*}{$L E V_{t}$} & 0.002 & 0.001 & -0.018 & 0.007 \\
\hline & $(0.071)$ & $(0.041)$ & $(-0.491)$ & $(0.295)$ \\
\hline \multirow[t]{2}{*}{$\operatorname{LOSS}_{t}$} & $0.169^{\star \star}$ & $0.145^{\star}$ & 0.133 & $0.169^{\star \star}$ \\
\hline & $(2.191)$ & (1.889) & (1.588) & $(2.368)$ \\
\hline \multirow[t]{2}{*}{ GROWTH $_{t}$} & 0.018 & $0.034^{\star \star}$ & -0.011 & 0.020 \\
\hline & (1.138) & $(2.107)$ & $(-0.680)$ & $(1.307)$ \\
\hline \multirow[t]{2}{*}{$B O A R D_{t}$} & $-0.037^{\star \star}$ & $-0.042^{\star \star}$ & 0.034 & -0.032 \\
\hline & $(-1.994)$ & $(-2.272)$ & $(0.945)$ & $(-1.619)$ \\
\hline \multirow[t]{2}{*}{$R E T_{t}$} & $-0.047^{\star \star}$ & $0.144^{\star \star \star}$ & $0.162^{\star \star \star}$ & $0.164^{\star \star \star}$ \\
\hline & $(-2.565)$ & (8.854) & (8.808) & $(9.077)$ \\
\hline \multirow[t]{2}{*}{ Constant } & 0.035 & -0.024 & $-0.237^{\star \star \star}$ & -0.004 \\
\hline & $(0.179)$ & $(-0.123)$ & $(-5.535)$ & $(-0.025)$ \\
\hline Year effects & Yes & Yes & Yes & Yes \\
\hline Industry effects & Yes & Yes & No & Yes \\
\hline Firm effects & No & No & Yes & No \\
\hline F-first stage & - & - & - & 682.593 \\
\hline Observations & 3,104 & 3,104 & 3,104 & 3,104 \\
\hline Adjusted $R^{2}$ & 0.339 & 0.330 & 0.347 & 0.338 \\
\hline
\end{tabular}

This table shows the robustness test results. Model (1) shows the results with another alternative measure of RKS's ECSR. Model (2) shows the results with the scores rating by "HEXUN" website for environmental corporate social responsibility. Model (3) shows the results using individual (firm) fixed-effects model. Model (4) shows the results under IV approach (the index from El Ghoul et al., 2011). 
TABLE 6 | The Logit model estimates the influence of covariates on environmental corporate social responsibility.

\begin{tabular}{|c|c|c|c|c|c|c|}
\hline \multirow{2}{*}{$\begin{array}{l}\text { Dependent variables }=\mathbf{G R}_{\boldsymbol{t}} \\
B T M_{t}\end{array}$} & \multirow{2}{*}{$\begin{array}{l}\text { Coef. } \\
0.372\end{array}$} & \multirow{2}{*}{$\begin{array}{c}\text { Std. err. } \\
0.047\end{array}$} & \multirow{2}{*}{$\frac{\boldsymbol{z}}{7.85}$} & \multirow{2}{*}{$\frac{P>|z|}{0.000}$} & \multicolumn{2}{|c|}{$95 \%$ Conf. Interval } \\
\hline & & & & & 0.279 & 0.465 \\
\hline$R O A_{t}$ & 0.168 & 0.058 & 2.87 & 0.004 & 0.053 & 0.282 \\
\hline$L E V_{t}$ & 0.169 & 0.060 & 2.82 & 0.005 & 0.052 & 0.286 \\
\hline $\operatorname{LOSS}_{t}$ & -0.058 & 0.217 & -0.27 & 0.791 & -0.484 & 0.368 \\
\hline GROWTH $_{t}$ & -0.020 & 0.039 & -0.53 & 0.596 & -0.096 & 0.055 \\
\hline$B O A R D_{t}$ & 0.254 & 0.045 & 6.23 & 0.000 & 0.174 & 0.333 \\
\hline$R E T_{t}$ & 0.162 & 0.045 & 3.64 & 0.000 & 0.075 & 0.250 \\
\hline Constant & -1.527 & 0.048 & -31.67 & 0.000 & -1.621 & -1.433 \\
\hline
\end{tabular}

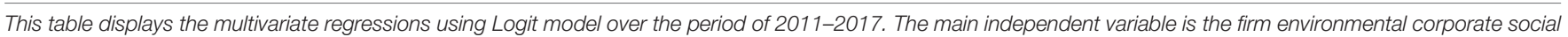
responsibility.

TABLE 7 | Estimated results of the average processing effect of environmental corporate social responsibility on firms' idiosyncratic risk.

\begin{tabular}{|c|c|c|c|c|c|c|c|}
\hline Dependent variables & & Sample & Treated group & Control group & ATT & Std. err. & $T$ stat \\
\hline \multirow[t]{4}{*}{$R / S K_{t+1}$} & & Unmatched & -0.178 & 0.022 & -0.200 & 0.042 & -4.75 \\
\hline & Matched & Kernel matching & -0.178 & -0.005 & -0.173 & 0.045 & -3.81 \\
\hline & & $k$-nearest Neighbor matchin $(k=4)$ & -0.178 & 0.003 & -0.181 & 0.050 & -3.63 \\
\hline & & Radius matching $(r=0.01)$ & -0.177 & -0.018 & -0.159 & 0.046 & -3.44 \\
\hline
\end{tabular}

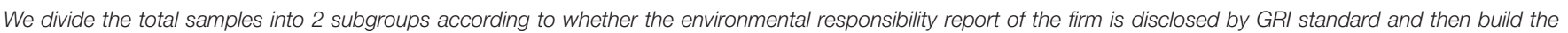

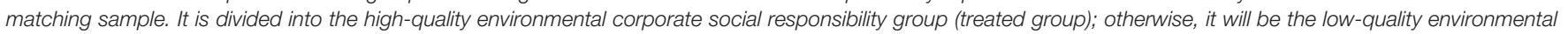
corporate social responsibility group (control group).

Referring to El Ghoul et al. (2011), we used the industry average ECSR score as the instrument. The Pearson correlation coefficient of the instrument and ECSR is significantly positive (not reported in the table), which indicates the effectiveness of the instrumental variable. The $F$-value of the first stage is 682.593 . In conclusion, instrumental variable is reliable and is not a weak instrumental variable. The result in columns (4) in Table 5 indicates a strong negative correlation between ECSR and firms' idiosyncratic risk. Thereby, the results are robust.

\section{Propensity score matching test}

Referring to Luo et al. (2019), we used the PSM test as another method to alleviate the endogenous problems. According to whether the Global Reporting Initiative (GRI) standard discloses the firm's environmental responsibility report, we divided the total samples into two groups. The GRI was founded in 1997 and is a joint initiative of the US non-governmental organization CERES and the UN Environment Programme. It is committed to developing a globally recognized reporting framework to provide guidance for sustainable development reporting and to overcome the loophole of government regulation. The final aim of GRI is to improve the quality, rigor, and practicality of sustainability reporting (Clarkson et al., 2008; Hahn and Lülfs, 2013). Therefore, it is scientific and feasible to adopt this standard for grouping. If a listed firm discloses its environmental responsibility report according to the GRI standard, it is divided into the high-quality ECSR group; otherwise, it is divided into the low-quality ECSR group. Then, we built the matching sample.

First, referring to Luo et al. (2019), we used the following Logit regression to estimate the propensity scores of ECSR in different firms. Among them, the explained variable GRI is a dummy variable reflecting the ECSR quality. The value is 1 when the firm discloses its environmental responsibility report following the GRI standard; otherwise, the value is 0 .

$$
\begin{aligned}
G R I_{i, t}= & \beta_{0}+\beta_{1}^{*} B T M_{i, t}+\beta_{2}^{*} R O A_{i, t}+\beta_{3}^{*} L E V_{i, t}+\beta_{4}^{*} L O S S_{i, t}+ \\
& \beta_{5}^{*} G R O W T H_{i, t}+\beta_{6}^{*} B O A R D_{i, t}+\beta_{7}^{*} R E T_{i, t}+\varepsilon_{i, t}
\end{aligned}
$$

From the estimation results in Table 6, it can be seen that the firm's book-to-market ratio, return on total assets, asset-liability ratio, the board size, and return on individual stocks will improve the quality of ECSR. If the company has better revenue, higher rate of return, and better management mechanism, its motivation to disclose non-financial information will be stronger. Besides, firms' loss in the previous year can reduce the disclosure quality of ECSR. The above results are similar to Chava (2014), Lu and Abeysekera (2014), and El Ghoul et al. (2018).

We then used three matching measures, including kernel matching, $k$-nearest neighbor matching, and radius matching. Before matching, we conducted a balance test and found that the control variables between the treatment and control groups are significantly different. After matching, the standardized deviations of most variables are decreased to less than $10 \%$, and the $t$-test is not significant. The results show that there is no significant difference in the matching variables between the two groups after the matching.

Table 7 shows the PSM test results; the estimation results of the different matching methods are the same. Furthermore, the coefficient of ATT of $R I S K_{t+1}$ is significantly negative at the $1 \%$ level. Overall, the PSM results generally support the riskreduction hypothesis. Through the above analysis, the previous research conclusions are still valid after controlling the potential endogenous problems. 
TABLE 8 | The relation between environmental corporate social responsibility and firms' idiosyncratic risk with additional control variables.

\begin{tabular}{|c|c|c|c|c|}
\hline \multirow{2}{*}{$\begin{array}{l}\text { Dependent variables } \\
\text { VAR }\end{array}$} & \multicolumn{4}{|c|}{ RISK $_{t+1}$} \\
\hline & ADV & $R \& D$ & Fdisp & Ferror \\
\hline \multirow[t]{2}{*}{$E C S R_{t}$} & $-0.051^{\star \star}$ & $-0.051^{\star \star}$ & $-0.052^{\star \star \star}$ & $-0.051^{\star \star \star}$ \\
\hline & $(-2.560)$ & $(-2.551)$ & $(-2.597)$ & $(-2.582)$ \\
\hline \multirow[t]{2}{*}{ BTMt } & $-0.071^{\star \star \star}$ & $-0.071^{\star \star \star}$ & $-0.072^{\star \star \star}$ & $-0.071^{\star \star \star}$ \\
\hline & $(-3.021)$ & $(-3.010)$ & $(-3.029)$ & $(-2.991)$ \\
\hline \multirow[t]{2}{*}{$R O A_{t}$} & $-0.059^{\star \star \star}$ & $-0.061^{\star \star \star}$ & $-0.060^{\star \star \star}$ & $-0.061^{\star \star \star}$ \\
\hline & $(-2.893)$ & $(-3.002)$ & $(-2.923)$ & $(-2.990)$ \\
\hline$L E V_{t}$ & 0.003 & 0.003 & 0.002 & 0.003 \\
\hline $\mathrm{GROWTH}_{t}$ & $(1.111)$ & $(1.160)$ & (1.229) & (1.198) \\
\hline \multirow[t]{2}{*}{$B O A R D_{t}$} & $-0.037^{\star \star}$ & $-0.037^{\star \star}$ & $-0.036^{\star}$ & $-0.036^{\star}$ \\
\hline & $(-2.011)$ & $(-1.994)$ & $(-1.937)$ & $(-1.953)$ \\
\hline \multirow[t]{2}{*}{$R E T_{t}$} & $0.163^{\star \star \star}$ & $0.164^{\star \star \star}$ & $0.165^{\star \star \star}$ & $0.165^{\star \star \star}$ \\
\hline & $(9.580)$ & (9.651) & (9.676) & (9.658) \\
\hline \multirow[t]{2}{*}{$V A R_{t}$} & $-0.032^{\star}$ & -0.018 & 0.017 & 0.007 \\
\hline & $(-1.825)$ & $(-1.180)$ & (1.223) & (0.539) \\
\hline \multirow[t]{2}{*}{ Constant } & 0.021 & 0.031 & 0.021 & 0.028 \\
\hline & $(0.107)$ & $(0.876)$ & $(0.108)$ & $(0.142)$ \\
\hline Year effects & Yes & Yes & Yes & Yes \\
\hline Industry effects & Yes & Yes & Yes. & Yes \\
\hline
\end{tabular}

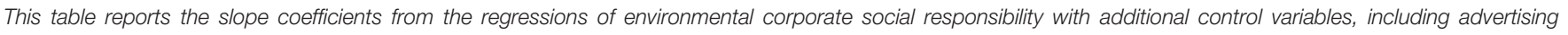

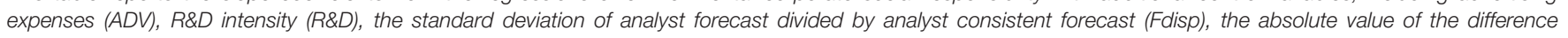
between the actual earnings share, and the consensus forecast of the analysts divided by the consensus forecast of the analysts (Ferror).

\section{Potential Interfering Factor}

Although we have used many control variables based on previous studies to enhance the explanatory power of the primary regression model, the model may still have the omitted variables bias. Referring to El Ghoul et al. (2011), Servaes and Tamayo (2013), and Cheng et al. (2020), we also added four important variables: (1) advertising expenses $\left(A D V_{i, t}\right)$, the natural logarithm of sales expenses to sales revenue; (2) R\&D intensity $\left(R \& D_{i, t}\right)$, the natural logarithm of R\&D investment to sales revenue; (3) Fdisp $_{i, t}$, the standard deviation of analyst forecast divided by analyst consistent forecast; (4) Ferror ${ }_{i, t}$, defined as the absolute value of the difference between the actual earnings share and the consensus forecast of the analysts divided by the consensus forecast of the analysts.

Specifically, advertising expenditure $\left(A D V_{i, t}\right)$ and $\mathrm{R} \& \mathrm{D}$ intensity $\left(R \& D_{i, t}\right)$ will promote ECSR to reduce the idiosyncratic risk. Firms with high advertising expenditure can expand the understanding among consumers and investors to establish product differentiation (Tang et al., 2012; Cavaco and Crifo, 2014). Similar to advertising expenses, considering the economic benefits brought by $R \& D$, the public tends to believe that firms with high R\&D expenses have stronger innovativeness, which can also bring positive feedback to firms. Finally, according to El Ghoul et al. (2011), neglecting analyst bias may mislead the estimation results. If the analyst forecast does not reasonably reflect the market's expectation of future earnings, then the estimation of risk may be biased.

Table 8 presents the results after adding additional control variables. In each regression, the coefficient of the explanatory variable $E C S R_{t}$ is still negative and is statistically significant at a level greater than $5 \%$. The results indicate that the explanatory variable is not sensitive to additional control variables. In general, the negative correlation between ECSR and firm risk is robust after considering the interference of other factors outside the model.

\section{Economic Channels}

Previous studies have shown that high-quality information disclosure can help investors to have a consistent understanding of the stock value. Thus, it is conducive to enhance the pricing 
TABLE 9 | Economic mechanisms between environmental corporate social responsibility and firms' idiosyncratic risk.

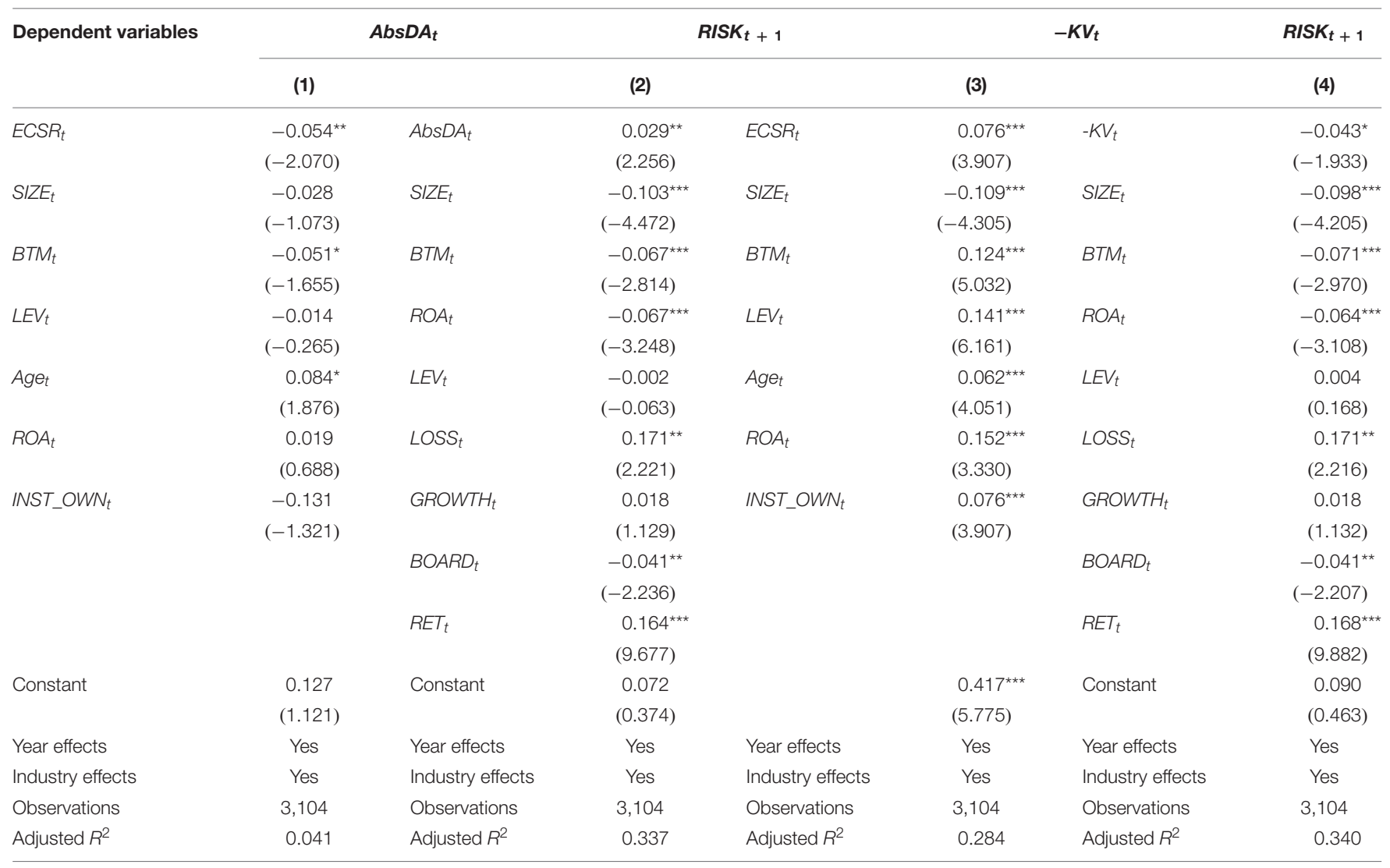

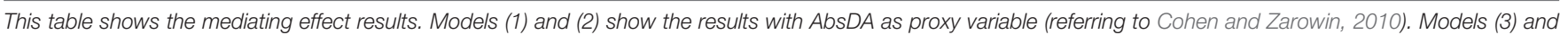

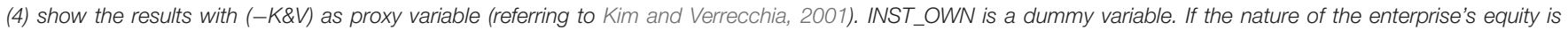
state-owned, it is assigned as 1; otherwise, it is 0 . Age represents the listing period of the enterprise.

efficiency of the market model and reduce the idiosyncratic risk of the stocks (Jiang et al., 2009; Lee and Liu, 2011; Ziegler et al., 2011). ECSR can effectively improve the information transparency by disclosing more information than by the financial statements (Bushee and Noe, 2000; Jiang et al., 2009). To confirm this potential transmission path, we used total absolute values of the discretionary accruals (AbsDA) and Kim and Verrecchia $(\mathrm{K} \& \mathrm{~V})$ index as proxy variables of information transparency and then used a two-step regression approach to test the mediating effect.

First, regarding Cohen and Zarowin (2010), we used the total absolute values of the discretionary accruals (AbsDA) over the past 3 years calculated from the Jones Model to measure the information transparency. The larger the AbsDA, the worse the information transparency. The first step is to use the following equation to conduct the firm's annual return by industry:

$$
\begin{gathered}
\frac{T_{i, t}}{\text { Assets }_{i, t-1}}= \\
k_{1} \frac{1}{\text { Assets }_{i, t-1}}+k_{2} \frac{\Delta \text { SALES }_{i, t}}{\text { Assets }_{i, t-1}}+ \\
k_{3} \frac{P P E_{i, t}}{\text { Assets }_{i, t-1}}+\varepsilon_{i, t}
\end{gathered}
$$

where $T A_{i, t}$ is the total accrual of firm $i$ in year $t$, and we define $T A_{i, t}=E B X I_{i, t}-C F O_{i, t}$. Among Eq. (5), EBXI $i, t$ is operating profit; $\mathrm{CFO}_{i, t}$ is net cash flow from operating activities in the statement of cash flows; Assets $_{i, t-1}$ represents the total assets with a lag of 1 year; $\triangle S A L E S_{i t}$ represents the increment in operating income, and $P P E_{i, t}$ is the (net fixed assets/total assets).

In the second step, the estimated regression coefficient is substituted into the following equation, and then the discretionary accruals are estimated: $\mathrm{DA}_{i, t}=(5)-(6)$

$$
N A_{i, t}=\hat{k}_{1} \frac{1}{\text { Assets }_{i, t-1}}+\hat{k}_{2} \frac{\Delta \operatorname{SALES}_{i, t}}{\text { Assets }_{i, t-1}}+\hat{k}_{3} \frac{P P E_{i, t}}{\text { Assets }_{i, t-1}}
$$

Third, information transparency (AbsDA) is equal to the sum of the absolute values of the discretionary accruals over the past 3 years.

$$
A b s D A=A b s\left(D A_{t-1}\right)+A b s\left(D A_{t-2}\right)+A b s\left(D A_{t-3}\right)
$$

Furthermore, as in Kim and Verrecchia (2001), we adopted the $\mathrm{K} \& \mathrm{~V}$ index as another method of measuring information transparency. For the convenience of empirical analysis, we adopted the negative value of $K \& V$ index $(-K \& V)$. Then we used Eq. (8) to regress all samples:

$$
\ln \left|\frac{\Delta P_{i, d, t}}{P_{i, d-1, t}}\right|=\alpha+\beta_{i, t}\left(\operatorname{Vol}_{i, d, t}-\operatorname{Vol}_{i, t}\right)+\mu_{i, t}
$$


TABLE 10 | Firm internal governance characteristics and the relation between environmental corporate social responsibility and firms' idiosyncratic risk.

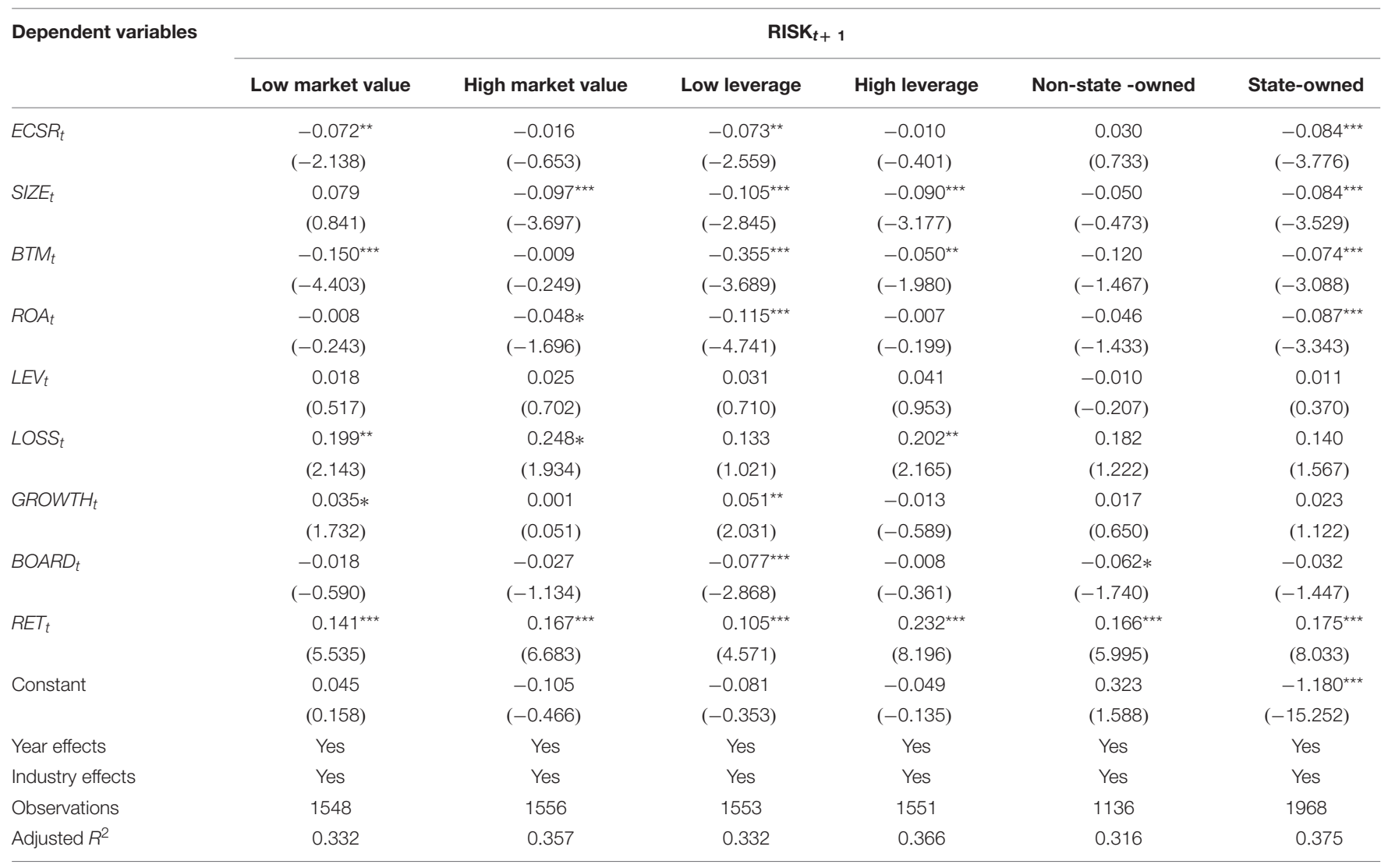

We divide the full sample into the following subgroups: low market value firms/high market value firms, low leverage firms/high leverage firms, and state-owned firms/nonstate-owned firms. We then rerun Eq. (4) using the subsamples with the period from 2011 to 2017, respectively.

$$
K \& V_{i, t}=\beta_{i, t} \times 1000000
$$

where $P_{i, d, t}$ is the closing price of stock $i$ on day $d$ of year $t$, and $V o l_{i, d, t}$ is the trading volume of stock $i$ on day $d$ of year $t . V o l_{i, t}$ is the average daily turnover of stock $i$ in year $t$. After the regression, we get the coefficient $\beta_{i, t}$. If the level of information disclosure is good, investors rely less on the trading volume information to make judgments and more on the firm's information disclosure. Therefore, the coefficient $\beta_{i, t}$ of the yield to the trading volume will be smaller. In brief, the larger the proxy variable $(-K \& V)$, the better the information transparency.

Finally, we use a two-step regression approach to analyze the mediating effect of information transparency in the process of ECSR affecting the firm's idiosyncratic risk. In the first step, we examine the relationship between ECSR and information transparency; second, we examine the effect of information transparency on the idiosyncratic risk. The regression equation is as follows:

$$
\begin{gathered}
\text { Opaque }_{i, t}=\alpha_{0}+\alpha_{1}^{*} \operatorname{ECSR}_{i, t}+\sum_{k} \gamma_{k} \text { Control }_{k, i, t}+\varepsilon_{i, t} \\
\operatorname{RISK}_{i, t+1}=\beta_{0}+\beta_{1}^{*}\left(-K \& V_{i, t}\right)+\sum_{k} \gamma_{k} \text { Control }_{k, i, t}+\varepsilon_{i, t}
\end{gathered}
$$

where Opaque $_{i, t}$ is the mediator variable, which is represented by $\mathrm{AbsDA}$ and $(-\mathrm{K} \& \mathrm{~V})$. As information transparency and environmental information disclosure affect the future risk of the company, the mediator variable should be the same period as the core explanatory variable ECSR, so it lags in the Eq. (11) with idiosyncratic risk.

As shown in columns (1) and (3) of Table 9, ECSR has a significant impact on the information transparency of the 2 measurement methods. Among them, the regression coefficient of the ECSR on the discretionary accruals (AbsDA) is -0.054 (with $t$-value $=-2.070$ ), which illustrates that the ECSR can reduce corporate earnings management. The regression coefficient of the ECSR on the $(-\mathrm{K} \& \mathrm{~V})$ is 0.076 (with $t$-value $=3.907$ ), which confirms the view that the ECSR can improve information transparency. The coefficients in columns (2) and (4) are 0.029 (with $t$-value $=2.256$ ) and -0.043 (with $t$-value $=-1.933$ ), respectively. Therefore, the results indicate that with the enhancement of the transparency of information disclosure, the firm's future risk is gradually decreased. In a word, the results in Table 9 show that high ECSR can significantly improve information transparency, alleviate the information asymmetry among stakeholders effectively, and thus reduce the risk. The above analysis provides strong support for Hypothesis 2. 
TABLE 11 | Firm external supervision characteristics and the relation between environmental corporate social responsibility and firms' idiosyncratic risk.

\begin{tabular}{|c|c|c|c|c|}
\hline \multirow[t]{2}{*}{ Dependent variables } & \multicolumn{4}{|c|}{$\mathrm{RISK}_{t+1}$} \\
\hline & Low audit quality & High audit quality & Low social responsibility quality & High social responsibility quality \\
\hline & $(-2.629)$ & $(-1.308)$ & $(-2.404)$ & $(-0.795)$ \\
\hline \multirow[t]{2}{*}{$S I Z E_{t}$} & $-0.093^{\star \star \star}$ & 0.014 & $-0.083^{\star \star \star}$ & $-0.184^{\star \star \star}$ \\
\hline & $(-3.643)$ & $(0.240)$ & $(-3.020)$ & $(-2.836)$ \\
\hline \multirow[t]{2}{*}{$R O A_{t}$} & $-0.058^{\star \star \star}$ & -0.074 & $-0.061^{\star \star \star}$ & -0.102 \\
\hline & $(-2.660)$ & $(-1.575)$ & $(-2.924)$ & $(-0.859)$ \\
\hline \multirow[t]{2}{*}{$L E V_{t}$} & -0.002 & 0.039 & 0.002 & 0.114 \\
\hline & $(-0.092)$ & $(0.734)$ & $(0.065)$ & $(0.607)$ \\
\hline $\operatorname{LOSS}_{t}$ & $0.163^{\star \star}$ & 0.270 & $0.163^{\star *}$ & $0.840^{\star *}$ \\
\hline$B O A R D_{t}$ & $(-1.507)$ & $(-1.258)$ & $(-1.938)$ & $(-0.171)$ \\
\hline \multirow[t]{2}{*}{$R E T_{t}$} & $0.155^{\star \star \star}$ & $0.259^{\star \star \star}$ & $0.158^{\star \star \star}$ & $0.266^{\star *}$ \\
\hline & (8.778) & $(4.192)$ & $(9.294)$ & $(1.968)$ \\
\hline \multirow[t]{2}{*}{ Constant } & 0.024 & $-1.147^{\star \star \star}$ & 0.038 & -0.039 \\
\hline & $(0.120)$ & $(-7.406)$ & (0.193) & $(-0.061)$ \\
\hline Year effects & Yes & Yes & Yes & Yes \\
\hline Industry effects & Yes & Yes & Yes & Yes \\
\hline Observations & 2805 & 299 & 3016 & 88 \\
\hline Adjusted $R^{2}$ & 0.329 & 0.440 & 0.334 & 0.560 \\
\hline
\end{tabular}

We divide the full sample into the following subgroups: low audit quality firms/high audit quality firms, low social responsibility quality firms/high social responsibility quality firms. We then rerun Eq. (4) using the subsamples with the period from 2011 to 2017, respectively.

\section{Further Analysis}

Corporate governance and the relationship between firms and government are important factors that affect firms' idiosyncratic risk (Ferreira and Laux, 2007; Chen and Liu, 2019). High market value firms and high leverage firms are generally considered to have good corporate governance (Jensen and Meckling, 1976). Thereby, to explore the negative effect of ECSR on idiosyncratic risk under different corporate characteristics, this article divides all samples into the following six subgroups based on market value, leverage, and nature of ownership (Benlemlih et al., 2018): low market value firms, high market value firms; low leverage firms, high leverage firms; and stateowned firms and non-state-owned firms. The high market value (low market value) firms consist of firms with average market values above (below) the median of all firms' market value; the high leverage (low leverage) firms consist of firms with average leverage above (below) the median of all firms' leverage. Then, we estimate the regression results by group. As shown in Table 10, ECSR $R_{t}$ coefficients of low market value firms, low leverage firms, and state-owned enterprises are negative above the $5 \%$ significance level. In contrast, the coefficients of the remaining groups are no longer significant. As discussed above, it can be seen that the ECSR plays a key role in firms with low information disclosure level, such as low market value firms and low leverage firms. State-owned firms have greater initiative to fulfill their environmental responsibilities, and the ECSR quality is higher. Therefore, compared with non-stateowned firms, the ECSR has a stronger inhibitory effect on idiosyncratic risk.

External supervision is also an important factor that affects firms' idiosyncratic risk (Abad and Robles, 2014; Yoshino et al., 2019). High audit quality firms and high social responsibility quality firms are generally considered to have a high level of external monitoring (Song and Li, 2010; Yuan et al., 2016). Thus, to explore the negative effect of ECSR on idiosyncratic risk under different external monitoring mechanisms, we classify all samples into the following four subgroups based on whether the company uses an international Big-4 auditing firm and whether a third party verifies the social responsibility report: low audit quality firms, high audit quality firms; and low social responsibility quality firms, high social responsibility quality firms. The grouping estimation results are shown in Table 11. As shown in the table, $E C S R_{i, t}$ coefficients of firms with low audit quality and low social responsibility quality are negative at greater than the $5 \%$ level, whereas other groups were insignificant. The results indicate that ECSR plays a better role in risk reduction in companies with weak external supervision. Based on the above analysis, we have reason to believe that Hypothesis 3 is true. 


\section{CONCLUSION}

Using a sample of Chinese A-share stocks disclosed environmental information from 2011 to 2017, this article explores the relationship between ECSR and firms' idiosyncratic risk. The empirical results show that the improvement of ECSR can significantly reduce firms' idiosyncratic risk in the future. By identifying the internal mechanism, this article profoundly discusses the impact of ECSR transmission mechanism on firms' idiosyncratic risk. Specifically, we find that the high-quality ECSR can effectively improve the level of information transparency and promote investors' understanding of the stock price to be consistent and thus reduce firms' idiosyncratic risk. Besides, evidence shows that the ECSR effect is more substantial for firms with low governance level firms, weak external supervision mechanism, and state-owned firms.

Our article has crucial policy implications for policy makers, firms, and other stakeholders. First, from the perspective of firms' idiosyncratic risk, this article supports the viewpoint that ECSR plays a positive role in stabilizing the market. Regulatory authorities should continue to strengthen the construction of environmental information disclosure system and then promote the systematization and standardization of firms' environmental information disclosure system. To further control firms' risk, the management should scientifically formulate the corporate strategy, enhance environmental awareness, and improve the quality of environmental responsibility disclosure. In this way, firms not only can control its own risks, but also help protect the environment. Stakeholders should examine the long-term performance and sustainable development ability of firms in an all-round way and take ECSR into the scope of measurement. Therefore, this article shows that as a strategy, firms' environmental performance should be highly valued by the government, management,

\section{REFERENCES}

Abad, P., and Robles, M. D. (2014). Credit rating agencies and idiosyncratic risk: is there a linkage? Evidence from the Spanish Market. Int. Rev. Econ. Finan. 33, 152-171. doi: 10.1016/j.iref.2014.05.002

Ambec, S., and Lanoie, P. (2008). Does it pay to be green? A systematic overview. Acad. Manag. Perspect. 22, 45-62. doi: 10.5465/amp.2008.35590353

Ang, A., Hodrick, R. J., Xing, Y., and Zhang, X. (2006). The cross-section of volatility and expected returns. J. Finan. 61, 259-299.

Ang, A., Hodrick, R. J., Xing, Y., and Zhang, X. (2009). High idiosyncratic volatility and low returns: international and further U.S. evidence. J. Finan. Econ. 91, 1-23. doi: 10.1016/j.jfineco.2007.12.005

Arouri, M., and Pijourlet, G. (2017). CSR performance and the value of cash holdings: international evidence. J. Bus. Ethics 140, 263-284. doi: 10.1007/ s10551-015-2658-5

Bansal, P., and Clelland, I. (2004). Talking trash: Legitimacy, impression management, and unsystematic risk in the context of the natural environment. Acad. Manag. J. 47, 93-103. doi: 10.2307/2015 9562

Barberis, N., and Huang, M. (2008). Stocks as lotteries: the implications of probability weighting for security prices. Am. Econ. Rev. 98, 2066-2100. doi: 10.1257/aer.98.5.2066

Barnea, A., and Rubin, A. (2010). Corporate social responsibility as a conflict between shareholders. J. Bus. Ethics 97, 71-86. doi: 10.1007/s10551-010-0496-Z and stakeholders. Second, our research found that ECSR and its economic impact are also believed to vary depending on the corporate characteristics and external monitoring mechanisms. ECSR plays a more critical role in firms with low governance level, firms with weak external supervision, and state-owned enterprises. Therefore, these groups of firms should pay more attention to their own environmental performance, gain competitive advantage through voluntary disclosure of environmental information and then achieve sustainable development.

\section{DATA AVAILABILITY STATEMENT}

The original contributions generated for this study are included in the article/supplementary material, further inquiries can be directed to the corresponding author/s.

\section{AUTHOR CONTRIBUTIONS}

YP: conceptualization and investigation. XK: data curation, formal analysis, and writing-original draft. HS: supervision. FT-H: validation. YP, HS, and FT-H: writing-review and editing. All authors contributed to the article and approved the submitted version.

\section{FUNDING}

This research was supported by Society for the Promotion of Science (JSPS) Kakenhi (2019-2020) Grant-in-Aid for Young Scientist No. 19K13742 and Grant-in-Aid for Excellent Young Researcher of the Ministry of Education of Japan (MEXT).

Ben-Amar, W., and McIlkenny, P. (2015). Board effectiveness and the voluntary disclosure of climate change information. Bus. Strategy Environ. 24, 704-719. doi: 10.1002/bse.1840

Benlemlih, M., Shaukat, A., Qiu, Y., and Trojanowski, G. (2018). Environmental and social disclosures and firm risk. J. Bus. Ethics 152, 613-626. doi: 10.1007/ s10551-016-3285-5

Bi, X., Peng, J., and Zuo, Y. Y. (2012). Environmental information disclosure system, corporate governance and environmental information disclosure (In Chinese). Account. Res. 7, 39-47.

Bushee, B. J., and Noe, C. F. (2000). Corporate disclosure practices, institutional investors, and stock return volatility. J. Account. Res. 38, 171-202. doi: 10.2307/ 2672914

Cai, L., Cui, J., and Jo, H. (2016). Corporate environmental responsibility and firm risk. J. Bus. Ethics 139, 563-594.

Cai, L., and He, C. (2014). Corporate environmental responsibility and equity prices. J. Bus. Ethics 125, 617-635. doi: 10.1007/s10551-013-1935-4

Cai, Y., Jo, H., and Pan, C. (2012). Doing well while doing bad? CSR in controversial industry sectors. J. Bus. Ethics 108, 467-480. doi: 10.1007/s10551-011-1103-7

Cavaco, S., and Crifo, P. (2014). CSR and financial performance: complementarity between environmental, social and business behaviours. Appl. Econ. 46, 33233338. doi: 10.1080/00036846.2014.927572

Chang, E. C., and Dong, S. (2006). Idiosyncratic volatility, fundamentals, and institutional herding: evidence from the Japanese stock market. Pac. Basin Finan. J. 14, 135-154. doi: 10.1016/j.pacfin.2005.09.001 
Chatzoglou, P., Chatzoudes, D., Amarantou, V., and Aggelidis, V. (2017). Examining the antecedents and the effects of CSR implementation: an explanatory study. EuroMed J. Bus. 12, 189-206.

Chava, S. (2014). Environmental externalities and cost of capital. Manag. Sci. 60, 2223-2247. doi: $10.1287 / \mathrm{mnsc} .2013 .1863$

Chen, Z., and Hamilton, T. (2020). What is driving corporate social and environmental responsibility in China? An evaluation of legacy effects, organizational characteristics, and transnational pressures. Geoforum 110, 116124. doi: 10.1016/j.geoforum.2020.02.004

Chen, Z. H., and Liu, Z. X. (2019). Government-enterprise relationship and firm idiosyncratic risk (In Chinese). J. Manag. Sci. 32, 48-61.

Cheng, F., Chiao, C., Fang, Z., Wang, C., and Yao, S. (2020). Raising short-term debt for long-term investment and stock price crash risk: evidence from China. Finan. Res. Lett. 33:101200. doi: 10.1016/j.frl.2019.05.018

Chok, J. I., and Sun, Q. (2007). Determinants of idiosyncratic volatility for biotech IPO firms. Finan. Manag. 36, 107-122.

Clarkson, P. M., Li, Y., Richardson, G. D., and Vasvari, F. P. (2008). Revisiting the relation between environmental performance and environmental disclosure: an empirical analysis. Account. Organ. Soc. 33, 303-327. doi: 10.1016/j.aos.2007. 05.003

Cohen, D. A., and Zarowin, P. (2010). Accrual-based and real earnings management activities around seasoned equity offerings. J. Account. Econ. 50, 2-19. doi: 10.1016/j.jacceco.2010.01.002

Connelly, B. L., Certo, S. T., Ireland, R. D., and Reutzel, C. R. (2011). Signaling theory: a review and assessment. J. Manag. 37, 39-67. doi: 10.1177/ 0149206310388419

Cordeiro, J. J., Profumo, G., and Tutore, I. (2020). Board gender diversity and corporate environmental performance: the moderating role of family and dual-class majority ownership structures. Bus. Strat. Environ. 29, 1127-1144. doi: $10.1002 /$ bse. 2421

Cordeiro, J. J., and Tewari, M. (2015). Firm characteristics, industry context, and investor reactions to environmental CSR: a stakeholder theory approach. J. Bus. Ethics 130, 833-849. doi: 10.1007/s10551-014-2115-x

Cormier, D., Aerts, W., Ledoux, M.-J., and Magnan, M. (2010). Attributes of social and human capital disclosure and information asymmetry between managers and investors. Can. J. Administr. 26, 71-88. doi: 10.1002/cjas.89

Cormier, D., and Gordon, I. M. (2001). An examination of social and environmental reporting strategies. accounting. Account. Audit. Account. J. 14, 587-617. doi: 10.1108/eum0000000006264

Cormier, D., and Magnan, M. (2014). The impact of social responsibility disclosure and governance on financial analysts' information environment. Corp. Govern. 14, 467-484. doi: 10.1108/cg-01-2013-0012

Cormier, D., and Magnan, M. (2015). The economic relevance of environmental disclosure and its impact on corporate legitimacy: an empirical investigation. Bus. Strat. Environ. 24, 431-450. doi: 10.1002/bse.1829

Dai, F. Z., and Yin, L. B. (2017). Does "face changing" behavior of securities analysts increase the idiosyncratic volatility of stocks? (In Chinese). Manag. Rev. 29, 14-22.

El Ghoul, S., Guedhami, O., Kim, H., and Park, K. (2018). Corporate environmental responsibility and the cost of capital: international evidence. J. Bus. Ethics 149, 335-361. doi: 10.1007/s10551-015-3005-6

El Ghoul, S., Guedhami, O., Kwok, C. C., and Mishra, D. R. (2011). Does corporate social responsibility affect the cost of capital? J. Bank. Finan. 35, 2388-2406. doi: 10.1016/j.jbankfin.2011.02.007

Elmagrhi, M. H., Ntim, C. G., Elamer, A. A., and Zhang, Q. (2019). A study of environmental policies and regulations, governance structures, and environmental performance: the role of female directors. Bus. Strat. Environ. 28, 206-220. doi: 10.1002/bse.2250

Fan, S., Opsal, S., and Yu, L. (2015). Equity anomalies and idiosyncratic risk around the world. Mult. Finan. J. 19, 33-75. doi: 10.17578/19-1-2

Ferreira, M. A., and Laux, P. A. (2007). Corporate governance, idiosyncratic risk, and information flow. J. Finan. 62, 951-989. doi: 10.1111/j.1540-6261.2007. 01228.x

Fu, M., Liu, Q. L., and Li, Y. (2015). Heterogeneous beliefs, financial statement quality and idiosyncratic volatility: a study based on difference model (In Chinese). Invest. Res. 34, 146-159.

Gaspar, J. M., and Massa, M. (2006). Idiosyncratic volatility and product market competition. J. Bus. 79, 3125-3152. doi: 10.1086/505251
Godfrey, P. C. (2005). The relationship between corporate philanthropy and shareholder wealth: a risk management perspective. Acad. Manag. Rev. 30, 777-798. doi: 10.5465/amr.2005.18378878

Godfrey, P. C., Merrill, C. B., and Hansen, J. M. (2009). The relationship between corporate social responsibility and shareholder value: an empirical test of the risk management hypothesis. Strat. Manag. J. 30, 425-445. doi: 10.1002/smj.750

Goyal, A., and Santa-Clara, P. (2003). Idiosyncratic risk matters! J. Finan. 58, 975-1007. doi: 10.1111/1540-6261.00555

Gregory, A., Tharyan, R., and Whittaker, J. (2014). Corporate social responsibility and firm value: disaggregating the effects on cash flow, risk and growth. J. Bus. Ethics 124, 633-657. doi: 10.1007/s10551-013-1898-5

Gu, M., Jiang, G. J., and Xu, B. (2019). The role of analysts: an examination of the idiosyncratic volatility anomaly in the Chinese stock market. J. Empir. Finan. 52, 237-254. doi: 10.1016/j.jempfin.2019.03.007

Hackston, D., and Milne, M. J. (1996). Some determinants of social and environmental disclosures in New Zealand companies. Account. Audit. Account. J. 9, 77-108. doi: 10.1108/09513579610109987

Han, S., You, W., and Nan, S. (2019). Zombie firms, external support and corporate environmental responsibility: evidence from China. J. Clean. Prod. 212, 14991517. doi: 10.1016/j.jclepro.2018.12.136

Hasseldine, J., Salama, A. I., and Toms, J. S. (2005). Quantity versus quality: the impact of environmental disclosures on the reputations of UK Plcs. Br. Account. Rev. 37, 231-248. doi: 10.1016/j.bar.2004.10.003

Hu, M., Zhang, D., Ji, Q., and Wei, L. (2020). Macro factors and the realized volatility of commodities: a dynamic network analysis. Resour. Policy 68:101813. doi: 10.1016/j.resourpol.2020.101813

Huang, W., Liu, Q., Rhee, S. G., and Zhang, L. (2010). Return reversals, idiosyncratic risk, and expected returns. Rev. Finan. Stud. 23, 147-168. doi: 10.1093/rfs/hhp015

Jensen, M. C., and Meckling, W. H. (1976). Theory of the firm: managerial behavior, agency costs and ownership structure. J. Finan. Econ. 3, 305-360. doi: 10.1016/0304-405x(76)90026-x

Jiang, G. J., Xu, D., and Yao, T. (2009). The information content of idiosyncratic volatility. J. Finan. Quant. Anal. 44, 1-28. doi: 10.1017/s0022109009090073

Jo, H., Kim, H., and Park, K. (2015). Corporate environmental responsibility and firm performance in the financial services sector. J. Bus. Ethics 131, 257-284. doi: 10.1007/s10551-014-2276-7

Jo, H., and Na, H. (2012). Does CSR reduce firm risk? Evidence from controversial industry sectors. J. Bus. Ethics 110, 441-456. doi: 10.1007/s10551-0121492-2

Jones, T. M. (1995). Instrumental stakeholder theory: a synthesis of ethics and economics. Acad. Manag. Rev. 20, 404-437. doi: 10.5465/amr.1995.9507312924

Khojastehpour, M., and Johns, R. (2014). The effect of environmental CSR issues on corporate/brand reputation and corporate profitability. Eur. Bus. Rev. 26, 330-339. doi: 10.1108/ebr-03-2014-0029

Kim, O., and Verrecchia, R. E. (2001). The relation among disclosure, returns, and trading volume information. Account. Rev. 76, 633-654. doi: 10.2308/accr.2001. 76.4.633

Lee, D. W., and Liu, M. H. (2011). Does more information in stock price lead to greater or smaller idiosyncratic return volatility? J. Bank. Finan. 35, 1563-1580. doi: 10.1016/j.jbankfin.2010.11.002

Li, J., Zhang, J., Zhang, D., and Ji, Q. (2019). Does gender inequality affect household green consumption behavior in China? Energy Policy 135:111071. doi: 10.1016/j.enpol.2019.111071

Li, X., Zhang, D., Zhang, T., Ji, Q., and Lucey, B. (2020). Awareness, energy consumption and pro-environmental choices of Chinese households. J. Clean. Prod. 279, 123734. doi: 10.1016/j.jclepro.2020.123734

Liu, W. Q., Xing, H. W., and Li, D. F. (2014). Information disclosure quality and "mystery of idiosyncratic volatility" (In Chinese). J. Shanxi Univ. 6, 115-124.

Liu, X., and Anbumozhi, V. (2009). Determinant factors of corporate environmental information disclosure: an empirical study of Chinese listed companies. J. Clean. Prod. 17, 593-600. doi: 10.1016/j.jclepro.2008.10.001

Lu, Y., and Abeysekera, I. (2014). Stakeholders' power, corporate characteristics, and social and environmental disclosure: evidence from China. J. Clean. Prod. 64, 426-436. doi: 10.1016/j.jclepro.2013.10.005

Luo, L., Lan, Y. C., and Tang, Q. (2012). Corporate incentives to disclose carbon information: evidence from the CDP Global 500 report. J. Int. Finan. Manag. Account. 23, 93-120. doi: 10.1111/j.1467-646x.2012.01055.x 
Luo, W., Guo, X., Zhong, S., and Wang, J. (2019). Environmental information disclosure quality, media attention and debt financing costs: evidence from Chinese heavy polluting listed companies. J. Clean. Prod. 231, 268-277. doi: 10.1016/j.jclepro.2019.05.237

Matsumura, E. M., Prakash, R., and Vera-Muñoz, S. C. (2014). Firm-value effects of carbon emissions and carbon disclosures. Account. Rev. 89, 695-724. doi: $10.2308 /$ accr- 50629

McMullen, D. K., and Ragahunandan. (1996). Internal control reportsand financial reporting problems. Account. Horizons 70, 67-75.

Meng, X. H., Zeng, S. X., and Tam, C. M. (2013). From voluntarism to regulation: a study on ownership, economic performance and corporate environmental information disclosure in china. J. Bus. Ethics 116, 217-232. doi: 10.1007/ s10551-012-1462-8

Mishra, S., and Modi, S. (2013). Positive and negative corporate social responsibility, financial leverage, and idiosyncratic risk. J. Bus. Ethics 117, 431-448. doi: 10.1007/s10551-012-1526-9

Orlitzky, M., and Benjamin, J. D. (2001). Corporate social performance and firm risk: a meta-analytic review. Bus. Soc. 40, 369-396. doi: 10.1177/ 000765030104000402

Ozdemir, O., Erkmen, E., and Kim, M. (2020). Corporate social responsibility and idiosyncratic risk in the restaurant industry: does brand diversification matter? Int. J. Contemp. Hosp. Manag. 32, 2925-2946. doi: 10.1108/ijchm-03-20200167

Phi, N. T. M., Taghizadeh-Hesary, F., Tu, C. A., Yoshino, N., and Kim, C. J. (2020). Performance differential between private and state-owned enterprises: an analysis of profitability and solvency. Emerg. Mark. Finan. Trade 1-16. doi: 10.1080/1540496X.2020.1809375

Salama, A., Anderson, K., and Toms, J. S. (2011). Does community and environmental responsibility affect firm risk? Evidence from U.K. panel data 1994-2006. Bus. Ethics Eur. Rev. 20, 192-204. doi: 10.1111/j.1467-8608.2011. 01617.x

Servaes, H., and Tamayo, A. (2013). The impact of corporate social responsibility on firm value: the role of customer awareness. Manag. Sci. 59, 1045-1061. doi: $10.1287 / \mathrm{mnsc} .1120 .1630$

Shahab, Y., Ntim, C. G., Chen, Y., Ullah, F., Li, H. X., and Ye, Z. (2020). Chief executive officer attributes, sustainable performance, environmental performance, and environmental reporting: New insights from upper echelons perspective. Bus. Strat. Environ. 29, 1-16. doi: 10.1002/bse.2345

Shahzad, F., Rehman, I. U., Nawaz, F., and Nawab, N. (2018). Does family control explain why corporate social responsibility affects investment efficiency? Corp. Soc. Respons. Environ. Manag. 25, 880-888. doi: 10.1002/csr.1504

Song, J. B., and Li, A. H. (2010). Research on corporate governance factors of corporate social responsibility (In Chinese). Res. Finan. Econ. Issues 5, 23-29. doi: $10.1017 / 9781108329453.003$

Taghizadeh-Hesary, F., Yoshino, N., Kim, C. J., and Mortha, A. (2019). A Comprehensive Evaluation Framework on the Economic Performance of StateOwned Enterprises. ADBI Working Paper 949. Tokyo: Asian Development Bank Institute.

Tan, M., and Liu, B. (2016). CEO's managerial power, board committee memberships and idiosyncratic volatility. Int. Rev. Finan. Anal. 48, 21-30. doi: 10.1016/j.irfa.2016.09.003

Tang, Z., Hull, C. E., and Rothenberg, S. (2012). How corporate social responsibility engagement strategy moderates the CSR-financial performance relationship. J. Manag. Stud. 49, 1274-1303. doi: 10.1111/j.1467-6486.2012.01068.x

Tencati, A., Perrini, F., and Pogutz, S. (2004). New tools to foster corporate socially responsible behavior. J. Bus. Ethics 53, 173-190. doi: 10.1023/b:busi. 0000039407.37497.44

Tian, X. L., Guo, Q. G., Han, C., and Ahmad, N. (2016). Different extent of environmental information disclosure across Chinese cities: contributing factors and correlation with local pollution. Glob. Environ. Change 39, 244-257. doi: 10.1016/j.gloenvcha.2016.05.014
Toms, J. S. (2002). Firm resources, quality signals and the determinants of corporate environmental reputation: some U.K. evidence. Br. Account. Rev. 34, 257-282. doi: 10.1006/bare.2002.0211

Tong, M. H., Xu, D. Y., and Zheng, T. W. (2020). Corporate environmental information disclosure and equity capital cost: an analysis of the mediating effect based on information transparency and social responsibility (In Chinese). Finan. Issues Res. 000, 63-71.

Tzouvanas, P., Kizys, R., Chatziantoniou, I., and Sagitova, R. (2020). Environmental disclosure and idiosyncratic risk in the European manufacturing sector. Energy Econ. 87:104715. doi: 10.1016/j.eneco.2020.104715

Wu, S. W., Lin, F., and Wu, C. M. (2014). Corporate social responsibility and cost of capital: an empirical study of the Taiwan stock market. Emerg. Mark. Finan. Trade 50(suppl. 1), 107-120. doi: 10.2753/ree1540-496x5001s107

Xiang, C., Chen, F., Jones, P., and Xia, S. (2020). The effect of institutional investors' distraction on firms' corporate social responsibility engagement: evidence from China. Rev. Manag. Sci. doi: 10.1007/s11846-020-00387-z [Epub ahead of print].

Yang, M., Hou, Y., Ji, Q., and Zhang, D. (2020). Assessment and optimization of provincial CO2 emission reduction scheme in China: an improved ZSG-DEA approach. Energy Econ. 91:104931. doi: 10.1016/j.eneco.2020.104931

Yang, Y., Li, Y. X., and Shen, H. T. (2011). Green financial policy, corporate governance and corporate environmental information disclosure: a case study of 502 listed companies in heavy pollution industries (In Chinese). Finan. Trade Res. 22, 131-139.

Ye, C. G., Wang, Z., Wu, J. F., and Li, H. (2015). External governance, environmental information disclosure and equity financing cost (In Chinese). Nankai Manag. Rev. 18, 85-96.

Yoshino, N., and Taghizadeh-Hesary, F. (2014). Analytical framework on credit risks for financing SMEs in Asia. Asia Pac. Dev. J. 21, 1-21. doi: 10.18356/ 18bfla40-en

Yoshino, N., and Taghizadeh-Hesary, F. (2015). Analysis of credit risk for small and medium-sized enterprises: evidence from Asia. Asian Dev. Rev. 32, 18-37. doi: 10.1162/adev_a_00050

Yoshino, N., Taghizadeh-Hesary, F., and Nili, F. (2019). Fair Premium rate of the Deposit Insurance system based on banks creditworthiness. Stud. Econ. Finan. 36, 8-31. doi: 10.1108/sef-05-2017-0105

Yuan, R., Sun, J., and Cao, F. (2016). Directors' and officers' liability insurance and stock price crash risk. J. Corp. Finan. 37, 173-192. doi: 10.1016/j.jcorpfin.2015. 12.015

Zhang, D., Li, J., and Ji, Q. (2020). Does better access to credit help reduce energy intensity in China? Evidence from manufacturing firms. Energy Policy 145:111710. doi: 10.1016/j.enpol.2020.111710

Zhang, X., Ma, M., and Chen, J. (2016). Regulation effect of external pressure to the enterprise environment disclosure (In Chinese). Soft Sci. 30, 74-78.

Ziegler, A., Busch, T., and Hoffmann, V. H. (2011). Disclosed corporate responses to climate change and stock performance: an international empirical analysis. Energy Econ. 33, 1283-1294. doi: 10.1016/j.eneco.2011.03.007

Zuo, H. M., Zheng, M., and Zhang, Y. (2011). Idiosyncratic volatility and crosssectional return: an explanation of the "idiosyncratic volatility puzzle" in the Chinese stock market (In Chinese). World Econ. 000, 117-135.

Conflict of Interest: The authors declare that the research was conducted in the absence of any commercial or financial relationships that could be construed as a potential conflict of interest.

Copyright (c) 2020 Kong, Pan, Sun and Taghizadeh-Hesary. This is an open-access article distributed under the terms of the Creative Commons Attribution License (CC BY). The use, distribution or reproduction in other forums is permitted, provided the original author(s) and the copyright owner(s) are credited and that the original publication in this journal is cited, in accordance with accepted academic practice. No use, distribution or reproduction is permitted which does not comply with these terms. 